\title{
GENERATION OF RBMK-1500 SPENT NUCLEAR FUEL ONE- GROUP CROSS-SECTION LIBRARIES AND THEIR EVALUATION AGAINST EXPERIMENTAL DATA
}

\author{
V. Barkauskas, R. Plukienė, A. Plukis, and V. Remeikis \\ Institute of Physics, Center for Physical Sciences and Technology, Savanoriu 231, LT-02300 Vilnius, Lithuania \\ E-mail: office@ftmc.lt; vytenis.barkauskas@ftmc.lt
}

Received 1 July 2016; revised 13 October 2016; accepted 21 December 2016

\begin{abstract}
Depletion of RBMK-1500 spent nuclear fuel (SNF) with and without an erbium burnable absorber was modelled, and onegroup burn-up dependent cross-section libraries for Origen-ARP were created. Depletion calculations for the generation of crosssection libraries were performed using the SCALE 6.1 code package with the TRITON control module, which employs the NEWT deterministic 2D transport code with the 238-group energy library based on the ENDF-B VII library and the ORIGEN-S nuclide composition calculation code. Concentrations of the most important actinides for criticality safety were calculated using the created libraries and were compared with the available experimental data and the newest modelling results. Available experimental data of fission products ( $\mathrm{Nd}$ and $\mathrm{Cs}$ isotopes) were also compared to the modelling results. Composition differences were evaluated for several fuel enrichments and water densities. The comparison shows an acceptable agreement between the values obtained using new one-group cross-section libraries and experimental data except for ${ }^{238} \mathrm{Pu}$ and ${ }^{241} \mathrm{Am}$, as well as the causes of discrepancy are discussed. It has been found that the enrichment and presence of the burnable absorber play an important role in the SNF composition. At the highest evaluated burn-up $(29 \mathrm{GWd} / \mathrm{tU})$ isotopic composition differences between $2 \%$ enrichment fuel and $2.8 \%$ burn-up for actinides important to burn-up credit (BUC) applications varied from 11 to $52 \%$.
\end{abstract}

Keywords: RBMK-1500 reactor, spent nuclear fuel, actinides, SCALE 6.1 modelling, one-group cross-sections

PACS: 28.41.Ak, 28.41.Kw, 28.50.Hw

\section{Introduction}

Issues of the nuclear safety of spent nuclear fuel (SNF) storage facilities are ones of the most challenging to the decommissioning stage after the final shutdown of two RBMK-1500 type units of the Ignalina Nuclear Power Plant. There are about 22000 assemblies of SNF which have to be safely stored until the final decision regarding the SNF management (reprocessing, disposal, etc.) is made. One of the key elements of safety analysis of these facilities is the SNF characterization regarding the radionuclide composition and related activity as well as the neutron emission. Information about the quantity of fissile isotopes in nuclear fuel also might be used for safeguard purposes [1]. The SNF composition determination using direct or indirect experimental techniques is rather expensive and technically complicated. Therefore, computer modelling is often used to evaluate SNF characteristics [2-4]. However, validation of these results is also essential: results of calculations of various complexity should correspond to available experimental knowledge [5-7].

New computational codes, improved computational speed and improved capabilities (e. g. 3D modelling geometry) for burn-up analysis allow evaluating the fuel depletion more precisely. Use of pre-generated reactor and burn-up specific cross-section libraries allows rapid simulating of the fuel composition and related parameters with acceptable accuracy [8]. This information might be used for various applications, e. g. as a reference point, designing experiments regarding determination of the fuel composition, proper evaluation of the effective neutron multiplication 
factor in systems with spent nuclear fuel, dose estimation in the case of probable accidents, etc. Availability of accurate and validated calculation results is essential for possible use of the burn-up credit in SNF storage facility safety analysis. Furthermore, information of the exact operating conditions might be used for the evaluation of a fast and sufficiently precise axial and horizontal composition profile.

Pre-generated burn-up specific cross-section libraries for several type reactors and fuels are validated and available [9]. Library for RBMK-1000 fuel depletion modelling also exists, however, there are no libraries for erbium fuel used in RBMK-1500 type reactors $[8,10]$. Calculations of the fuel depletion in the RBMK-1500 type reactor and the generation of one-group cross-section libraries for SNF composition calculations with ORIGEN-ARP for erbium fuel are presented in this paper. In order to introduce onegroup cross-section libraries for burn-up credit calculations of RBMK-1500 spent nuclear fuel, the focus on the precise evaluation (taking into account comparison of calculation results against experimental data) of fissile and non-fissile actinides which are important to burn-up credit calculations is made. Available experimental data of fission products ( $\mathrm{Nd}$ and Cs isotopes) were also compared with the modelling results.

Concentrations of the selected actinides $\left({ }^{234} \mathrm{U},{ }^{235} \mathrm{U}\right.$, $\left.{ }^{236} \mathrm{U},{ }^{238} \mathrm{Pu},{ }^{239} \mathrm{Pu},{ }^{240} \mathrm{Pu},{ }^{241} \mathrm{Pu},{ }^{242} \mathrm{Pu},{ }^{237} \mathrm{~Np},{ }^{241} \mathrm{Am},{ }^{243} \mathrm{Am}\right)$ were calculated for RBMK-1500 erbium fuel and for non-erbium fuel taking into account different reactor operation conditions. The obtained results were compared to existing experimental data and results of other calculations. Actinides used for "actinide-only" calculations were taken from the NEA study [11]. Besides, ${ }^{242} \mathrm{Cm}$ and ${ }^{244} \mathrm{Cm}$ concentrations were evaluated. $\mathrm{Cm}$ isotopes are important for the thermal and radiation shielding evaluation during dry storage, but not so vital regarding burn-up credit calculations. ${ }^{142} \mathrm{Nd},{ }^{143} \mathrm{Nd},{ }^{144} \mathrm{Nd},{ }^{145} \mathrm{Nd},{ }^{146} \mathrm{Nd},{ }^{148} \mathrm{Nd},{ }^{150} \mathrm{Nd}$ and ${ }^{137} \mathrm{Cs}$ concentrations were also calculated, as experimental data, although limited, exist for them too. Concentration ratios of these nuclides are often used to precisely evaluate the burn-up of nuclear fuel [12].

Only limited experimental data are available for the composition of RBMK-1000 type reactor fuel [5, 6, especially regarding fuel with an erbium burnable absorber used in the Ignalina NPP RBMK-1500 type reactors. Most of RBMK-1000 reactor physical characteristics are very similar to those of RBMK-1500, therefore the use of experimental data from RBMK1000 could be justified. Also, some modelling was performed earlier in this area: MCNP and ORIGEN codes were used for the depletion calculations of
RBMK-1000 fuel (including comparison with experimental data) in [2, 4, 13]. The SCALE code system and the HELIOS code were used to calculate concentrations of some nuclides in [14]. RBMK-1500 type reactor SNF depletion calculations and SNF storage cask criticality calculations were performed in [15]. Furthermore, there were some studies related with the Ignalina NPP decommissioning projects [16].

\section{Methodology}

The SCALE 6.1 code package, which is widely used for criticality and burn-up calculations to justify safety of various activities in nuclear field, was used for calculations [17]. The TRITON control module employing NEWT (2D geometry and deterministic calculation method to solve neutron transport equations and calculate neutron flux) and ORIGEN-S (used for depletion calculations) codes was used to generate cross-section libraries. Cross-sections of nuclides were obtained from the ENDF/B-VII.0 cross-section data library.

The NEWT code is used to solve the Boltzmann's transport equation for neutrons

$$
\hat{\Omega} \cdot \nabla_{\psi}(\vec{r}, \hat{\Omega}, E)+\Sigma_{t}(\vec{r}, E) \psi(\vec{r}, \hat{\Omega}, E)=Q(\vec{r}, \hat{\Omega}, E),(1)
$$

where $\psi(\vec{r}, \hat{\Omega}, E)$ is the angular flux at position $\vec{r}$, in direction $\hat{\Omega}$ at energy $E, \Sigma_{\mathrm{t}}(\vec{r}, E)$ is the total macroscopic cross section at position $\vec{r}$ and energy $E$, $Q(\vec{r}, \hat{\Omega}, E)$ is the source at position $\vec{r}$, in direction $\hat{\Omega}$ and at energy $E, \vec{\nabla}$ is the vector differential operator. The source $Q$ is generally composed of three terms: a scattering source, a fission source and an external or fixed source.

In general, this transport equation can be difficult to apply and solve analytically. Hence, simplifications and numerical approximations are used in the NEWT code to solve the equation.

ORIGEN-S solves the Bateman equation for systems with neutron flux and calculates the atom density of a set of chosen nuclides,

$$
\frac{\mathrm{d} N_{i}}{\mathrm{~d} t}=\sum_{j=1}^{m} l_{i j} \lambda_{j} N_{j}+\bar{\Phi} \sum_{k=1}^{m} f_{i k} \sigma_{k} N_{k}-\left(\lambda_{\mathrm{i}}+\bar{\Phi} \sigma_{\mathrm{i}}\right),(2)
$$

where $N_{\mathrm{i}}$ is the atom density of nuclide $i, \lambda_{\mathrm{i}}$ is the radioactive disintegration constant of nuclide $i, \sigma_{\mathrm{i}}$ is the spectrum-averaged microscopic neutron absorption cross-section of nuclide $i, \bar{\Phi}$ is the space- and energy-averaged neutron flux, $l_{i j}$ are the branching fractions of radioactive disintegrations from other nuclide $j$ to nuclide $i, f_{i k}$ are branching fractions for neutron absorption by other nuclides $k$ that lead to the formation of species $i$. 
ORIGEN-ARP was used to perform point-depletion calculations with the ORIGEN-S code using the problem-dependent cross-section libraries which were generated using the ARP (Automatic Rapid Processing) module. There are a number of prepared cross-section libraries available within the SCALE for different reactors and fuels [8, 10].

The cross-sections for uranium-based fuels mainly depend on fuel enrichment, burn-up and water density during burn-up as described in [18]. A set of libraries was generated changing the abovementioned parameters. These libraries are used for the interpolation of cross-sections of desired fuel parameters.

The interpolation of cross-section libraries which are used by ORIGEN-S is performed as a function of burn-up first, and then other parameters (enrichment, moderator density) are additionally used for interpolation as it will be explained in more detail in the next section.

\section{Model and calculations}

A simplified model of the RBMK-1500 reactor core fragment with 14 fuel assemblies and 2 control rods distributed according to the real RBMK-1500 reactor core geometry was used for modelling, see Fig. 1 . The control and protection system (CPS) rod with the neutron absorber $\mathrm{B}_{4} \mathrm{C}$ as used in the original design of RBMK was inserted and the other CPS rod was extracted, while channels were filled with water of the chosen density.

The RBMK-1500 fuel assembly consists of 2 fuel bundles, each of them having 18 fuel rods arranged in two concentric rings with the central carrier rod at the centre. The fuel rod was treated as a zirconium alloy tube homogeneously filled with uranium dioxide with or without a burnable erbium absorber. The pellet density was reduced to ensure that the amount of fuel material inside the tube corresponds to the actual data [19]. The gap between the pellet and cladding as well as the hole in the middle of the pellet were excluded to simplify the geometry and reduce the computational time. The central carrier rod was defined as a hollow tube made of zirconium alloy. Water as a moderator and a lattice cell with a triangular pitch with half-pitch of $0.802 \mathrm{~cm}$ were chosen for self-shielding calculations in the CENTRM module [ 3,20 ]. Periodical boundary conditions were applied for reactor segment walls, which correspond to an infinite lattice comprised of such segments and are suitable for efficient modelling of neutron fluxes in the RBMK-1500 reactor core.

The power of the fuel assembly was chosen to be constant. Temperatures of graphite and cooling water were kept equal to 873 and $567 \mathrm{~K}$, respectively, which correspond to the real operating conditions of the RBMK-1500 reactor [19]. The density of cooling water in the model varied from 0.4 to $0.8 \mathrm{~g} / \mathrm{cm}^{3}$ and the density of graphite was $1.675 \mathrm{~g} / \mathrm{cm}^{3}$. The average $k_{\text {eff }}$ value of such a system for $12 \mathrm{GWd} / \mathrm{tU}$ burn-up fuel varied from 0.934 (for $2 \%$ enrichment with no erbium, $0.4 \mathrm{~g} / \mathrm{cm}^{3}$ water density) to 1.012 (for $2.8 \%$ enrichment with erbium, $0.4 \mathrm{~g} / \mathrm{cm}^{3}$ water density). The $k_{\text {eff }}$ uncertainty (convergence criterion of calculations) did not exceed 0.001 .

Depletion calculations for the preparation of cross-section libraries consisted of two steps. The first step was the depletion of fresh fuel in all fuel channels to the average burn-up ( $12 \mathrm{GWd} / \mathrm{tU})$. The second step was the depletion of fuel in one fuel channel (marked channel in Fig. 1), while the composition (set of 100 nuclides consisting of initial fuel material, activation and fission products) taken from the first step calculations and corresponding to the average fuel burnup was kept constant in the remaining fuel channels. The neutron fluxes were calculated by the NEWT module using three 160 day time steps (power was kept constant: $25 \mathrm{MW} / \mathrm{tU}$, corresponding reactor thermal power $4700 \mathrm{MW}$ ) for the first step calculations, and the average burn-up was achieved at all fuel channels after this step. The second step calculations for libraries were performed using a more detailed 100-day time step, keeping $25 \mathrm{MW} / \mathrm{tU}$ power

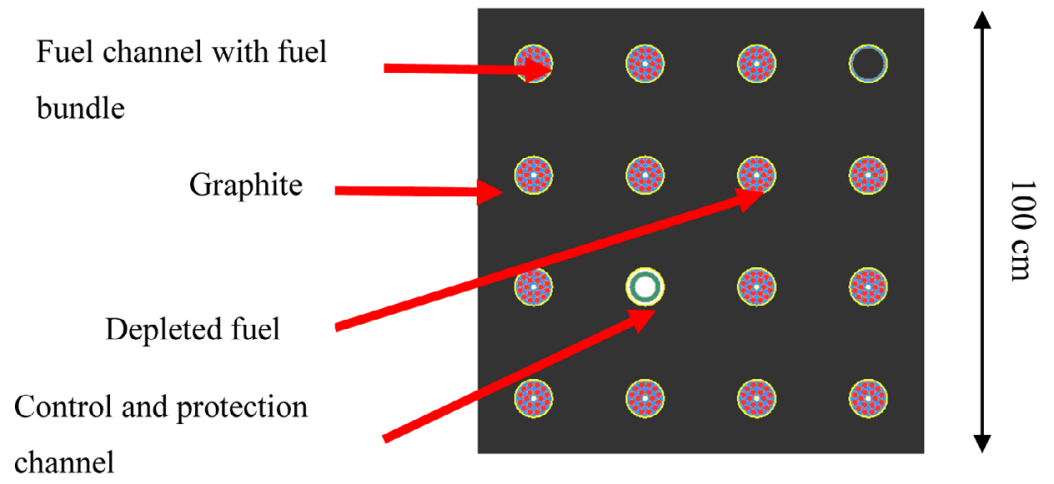

Fig. 1. RBMK-1500 reactor lattice with fuel (14) and CPS (2) channels. Fuel assembly in the "depleted fuel" channel was used for depletion calculations to obtain cross-section libraries. 
constant up to $30 \mathrm{GWd} / \mathrm{tU}$ burn-up. The same procedure was applied for non-erbium fuel with $2 \%$ enrichment and $2.4 \%$ (with $0.41 \%$ mass of $\mathrm{Er}_{2} \mathrm{O}_{3}$ burnable absorber), 2.6\% (0.5\% $\left.\mathrm{Er}_{2} \mathrm{O}_{3}\right)$ and $2.8 \%\left(0.6 \% \mathrm{Er}_{2} \mathrm{O}_{3}\right)$ enrichment fuel with the erbium burnable absorber. The natural erbium isotopic composition was used for calculations $\left(1.7 \%{ }^{164} \mathrm{Er}, 33.4 \%{ }^{166} \mathrm{Er}, 22.9 \%{ }^{167} \mathrm{Er}\right.$, $\left.26.9 \%{ }^{168} \mathrm{Er}, 15.1 \%{ }^{170} \mathrm{Er}\right)$.

After these steps, files containing cross-section libraries were collected and grouped taking into account the enrichment and water density used in the calculations. Two separate libraries were created: the first one for $2.0 \%$ enrichment fuel without erbium and the second one for $2.4-2.8 \%$ enrichment erbium fuel depending on different initial fuel composition. Cross-sections were stored as average one-group values that were obtained by weighting multi-group neutron cross-sections.

One-group cross section libraries are most sensitive to three parameters: initial enrichment, burn-up and moderator density. The role of other parameters (temperatures of the components, cladding thickness, rod lattice pitch) on the spent nuclear fuel isotopic concentration was found to be negligible by other authors [21], therefore only three main parameters were used for library generation.

\section{Results}

In order to validate the modelling results, available RBMK-1000 reactor fuel experimental data [5, 6] and independent TRITON point-depletion calculations results [ $[$ ] were used to assure that the concentrations predicted by generated cross-section libraries are in a satisfactory agreement. More detailed TRITON calculations are available only for ${ }^{238} \mathrm{Pu}$ and ${ }^{240} \mathrm{Pu}$. For all nuclides only data from two different burn-up fuel assemblies for $2 \%$ enrichment fuel are available. Due to different positions of the fuel samples taken for destructive examination, their burn-up was re-evaluated taking into account the concentrations of $\mathrm{Nd}$ isotopes [12]. Data for 2.02 and $2.09 \%$ initial enrichment fuel are also available [6]. Attention should be drawn that the experimental data given in [5, 6] are the same, although in [5] the initial enrichment was reported to be $2 \%$ in all fuel samples.

The nuclide concentration dependence on the burn-up and coolant density for the validation of cross-section library results was evaluated using the ORIGEN-ARP code. Two cases were analyzed: the constant power and the constant neutron fluence. The average power of $22.5 \mathrm{MW} / \mathrm{tU}$ was used for constant power calculations and the initial pow- er of $22.5 \mathrm{MW} / \mathrm{tU}$ for fresh fuel was used in the constant neutron fluence case. The coolant density values varied from 0.4 to $0.8 \mathrm{~g} / \mathrm{cm}^{3}$.

The concentrations of actinides important to the burn-up credit $\left({ }^{234} \mathrm{U},{ }^{235} \mathrm{U},{ }^{236} \mathrm{U},{ }^{238} \mathrm{Pu},{ }^{239} \mathrm{Pu},{ }^{240} \mathrm{Pu}\right.$, $\left.{ }^{241} \mathrm{Pu},{ }^{242} \mathrm{Pu},{ }^{237} \mathrm{~Np},{ }^{241} \mathrm{Am},{ }^{243} \mathrm{Am}\right)$ as well as those of some fission products $\left({ }^{42} \mathrm{Nd},{ }^{143} \mathrm{Nd},{ }^{144} \mathrm{Nd},{ }^{145} \mathrm{Nd}\right.$, ${ }^{146} \mathrm{Nd},{ }^{148} \mathrm{Nd},{ }^{150} \mathrm{Nd}$ and ${ }^{137} \mathrm{Cs}$ ) were calculated for RBMK-1500 erbium fuel and for non-erbium fuel. Comparison was made for the calculated and experimentally measured concentrations expressed in grams of a certain isotope per metric ton of ${ }^{238} \mathrm{U}$.

\subsection{Uranium isotopes}

Differences for selected uranium isotopes are mainly determined by the initial composition, therefore the largest differences for different enrichment fuel are observed for the ${ }^{234} \mathrm{U}$ (Fig. 2) and ${ }^{235} \mathrm{U}$ (Fig. 3) isotopes. The difference is proportional to the difference of initial enrichment. The experimental values for $2 \%$ enrichment fuel show a satisfactory agreement (difference between experimental and calculated values is $9-14 \%$ for ${ }^{234} \mathrm{U}, 13-16 \%$ for ${ }^{235} \mathrm{U}, 5-14 \%$ for ${ }^{236} \mathrm{U}$ (Fig. 4)) with the values obtained using the generated cross-section. Difference between experimental and calculated values in the case of ${ }^{234} \mathrm{U}$ isotope is mainly caused by a slightly different initial composition of 2.02 and $2.09 \%$ initial enrichment fuel, but the computational evaluation follows the experimental tendency of a linear decrease of ${ }^{234} \mathrm{U}$ concentration as burn-up increases.

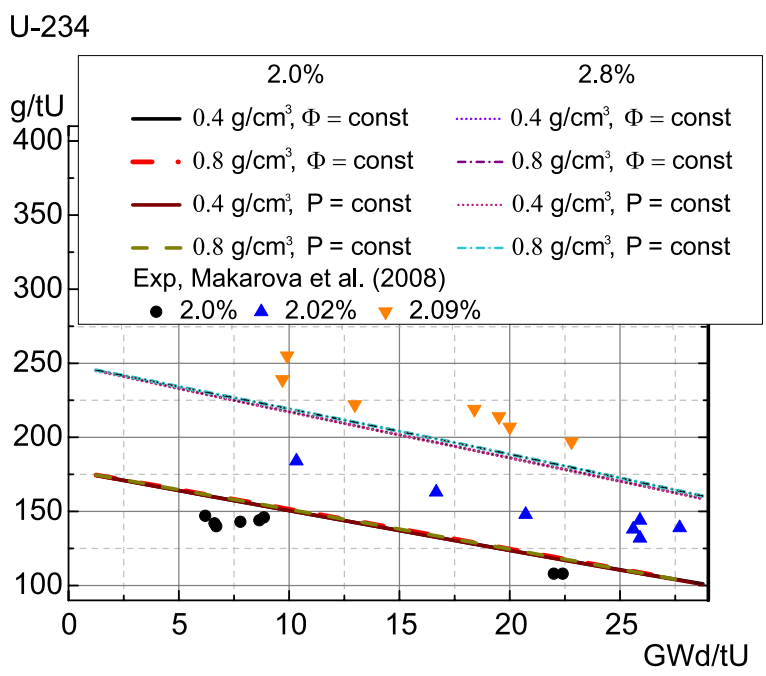

Fig. 2. ${ }^{234} \mathrm{U}$ concentrations for different enrichment RBMK-1500 fuel calculated using generated neutron cross-section libraries in constant flux and constant power cases and experimental points from [6]. 


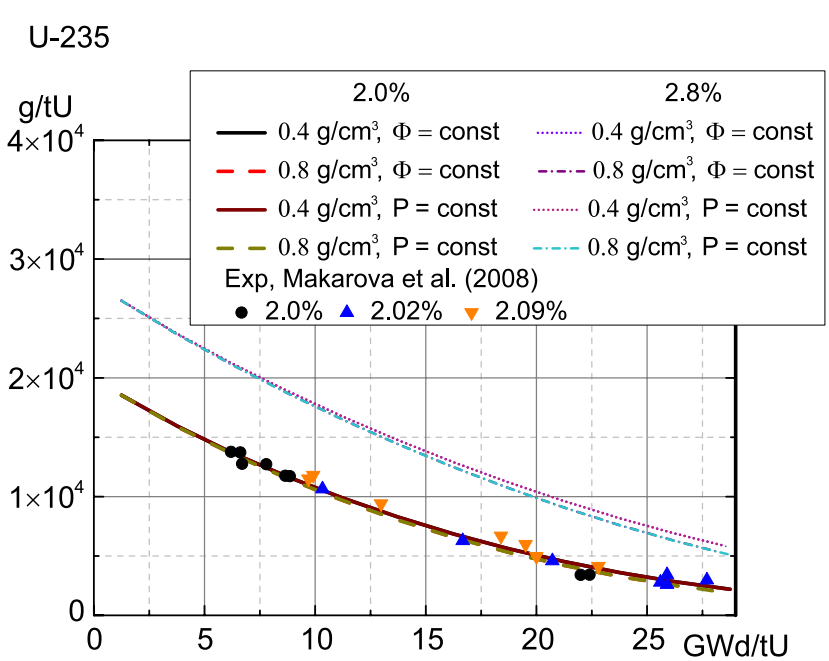

Fig. 3. ${ }^{235} \mathrm{U}$ concentrations for different enrichment RBMK-1500 fuel calculated using generated neutron cross-section libraries in constant flux and constant power cases and experimental points from [6].

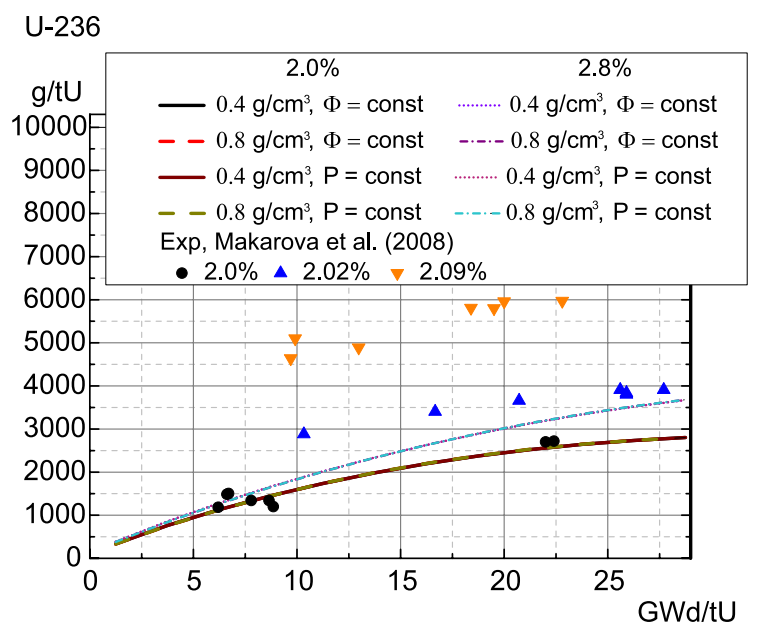

Fig. 4. ${ }^{236} \mathrm{U}$ concentrations for different enrichment RBMK-1500 fuel calculated using generated neutron cross-section libraries in constant flux and constant power cases and experimental points from [6].

${ }^{236} \mathrm{U}$ differences in the experimental data for 2.02 and $2.09 \%$ initial enrichment fuel are assumed to be caused by a different initial composition due to the fact that 2.02 and $2.09 \%$ initial enrichment fuel is manufactured using the regenerated uranium obtained through reprocessing of either SNF or nuclear weapons. The modelled concentrations of ${ }^{235} \mathrm{U}$ show a good agreement with the experimental results.

\subsection{Plutonium isotopes}

Plutonium isotopes are analyzed considering a different enrichment of RBMK-1500 fuel and com-

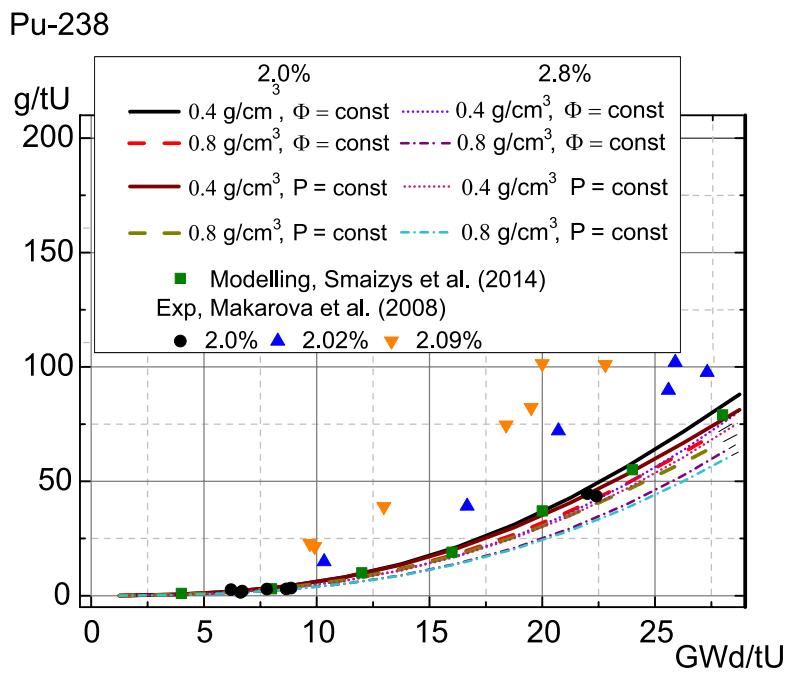

Fig. $5 .{ }^{238} \mathrm{Pu}$ concentrations for different enrichment RBMK-1500 fuel calculated using generated neutron cross-section libraries in constant flux and constant power cases and experimental points from [6] as well as point depletion modelling results from [4].

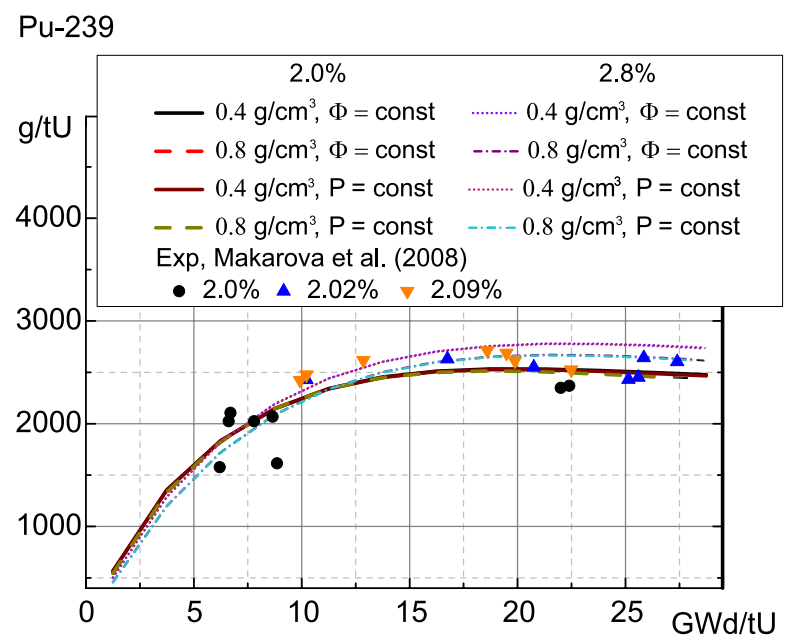

Fig. $6 .{ }^{239} \mathrm{Pu}$ concentrations for different enrichment RBMK-1500 fuel calculated using generated neutron cross-section libraries in constant flux and constant power cases and experimental points from [6].

pared with the existing experimental data for ${ }^{238} \mathrm{Pu}$ (Fig. 5), ${ }^{239} \mathrm{Pu}$ (Fig. 6), ${ }^{240} \mathrm{Pu}$ (Fig. 7), ${ }^{241} \mathrm{Pu}$ (Fig. 8) and ${ }^{242} \mathrm{Pu}$ (Fig. 9). The concentrations of plutonium ${ }^{238} \mathrm{Pu},{ }^{240} \mathrm{Pu},{ }^{241} \mathrm{Pu},{ }^{242} \mathrm{Pu}$ isotopes in nuclear fuel are highest in $2.0 \%$ enrichment fuel, with the exception of ${ }^{239} \mathrm{Pu}$ (modelled concentration of ${ }^{239} \mathrm{Pu}$ is highest in $2.8 \%$ enrichment fuel).

In the case of ${ }^{238} \mathrm{Pu}$, the experimental values exceeded the modelled results up to 2 times for the 2.02 and $2.09 \%$ initial enrichment fuel, and this is caused by a different initial concentration of 


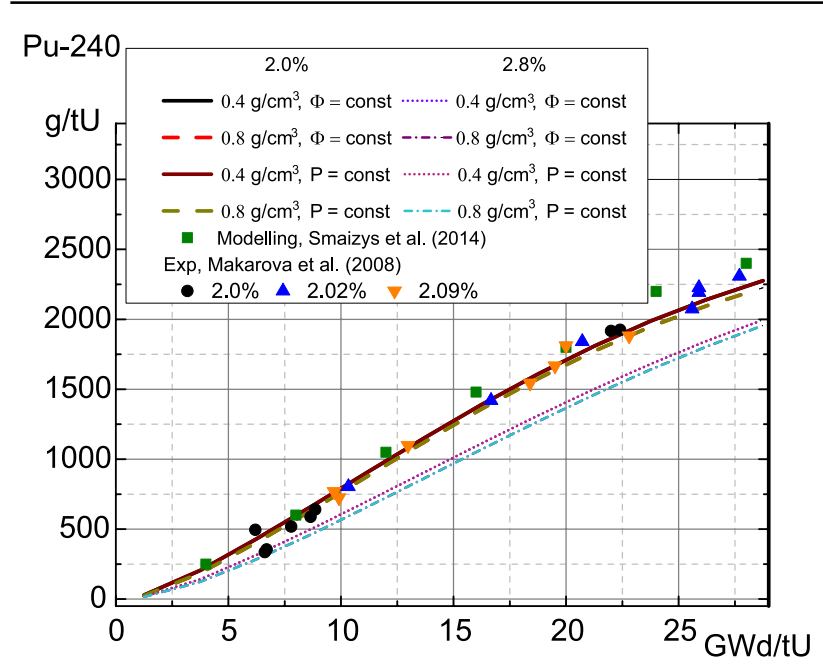

Fig. 7. ${ }^{240} \mathrm{Pu}$ concentrations for different enrichment RBMK-1500 fuel calculated using generated neutron cross-section libraries in constant flux and constant power cases and experimental points from [6] as well as point depletion modelling results from [4].

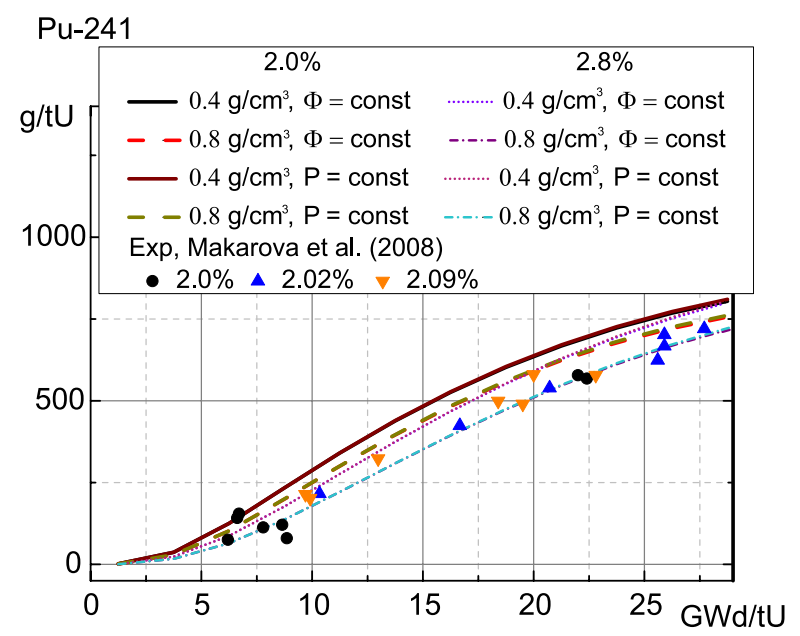

Fig. 8. ${ }^{241} \mathrm{Pu}$ concentrations for different enrichment RBMK-1500 fuel calculated using generated neutron cross-section libraries in constant flux and constant power cases and experimental points from [6].

the parent nuclide ${ }^{237} \mathrm{~Np}$ which is obtained through the activation of ${ }^{236} \mathrm{U}$ discussed above. Agreement of the experimental data [6] and the calculated values is satisfactory for other plutonium isotopes - the difference between the experimental and calculated values is $5-6 \%$ for ${ }^{239} \mathrm{Pu}, 5-25 \%$ (the highest difference for low burn-up) for ${ }^{240} \mathrm{Pu}, 5-15 \%$ for ${ }^{241} \mathrm{Pu}$ and $5-19 \%$ for ${ }^{242} \mathrm{Pu}$. The calculations of this study show a good agreement with TRITON point-depletion calculations of other authors [4].

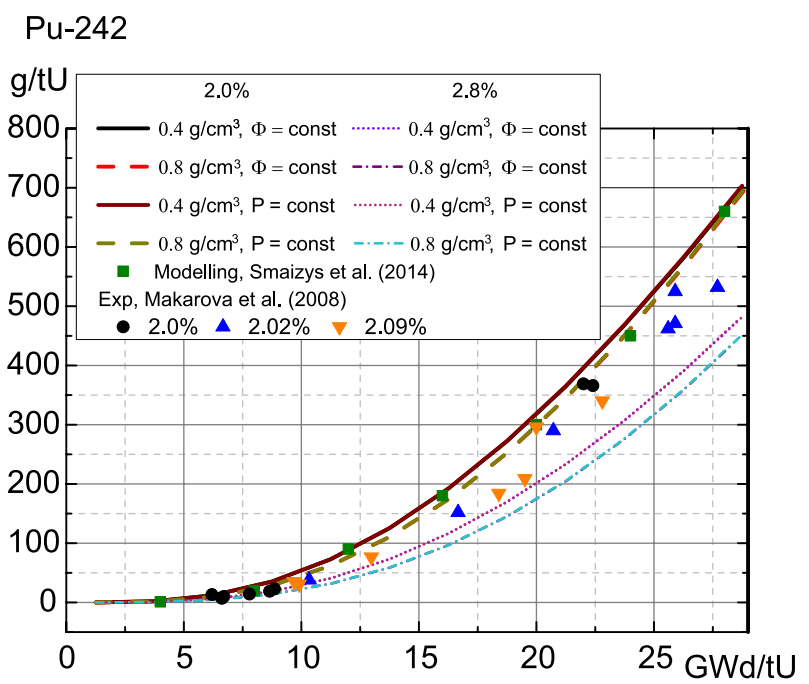

Fig. 9. ${ }^{242} \mathrm{Pu}$ concentrations for different enrichment RBMK-1500 fuel calculated using generated neutron cross-section libraries in constant flux and constant power cases and experimental points from [6] as well as point depletion modelling results from [4].

\subsection{Americium and neptunium}

The modelled concentration of ${ }^{241} \mathrm{Am}$ (Fig. 10) does not correspond to the experimental values of [6]. Analyzing other studies performed in this field [f] it was found that possible concentrations of ${ }^{241} \mathrm{Am}$ in other reactor types show similar results, therefore it is possible that the experimental values are either incorrect or are not presented correctly. Assuming

Am-241

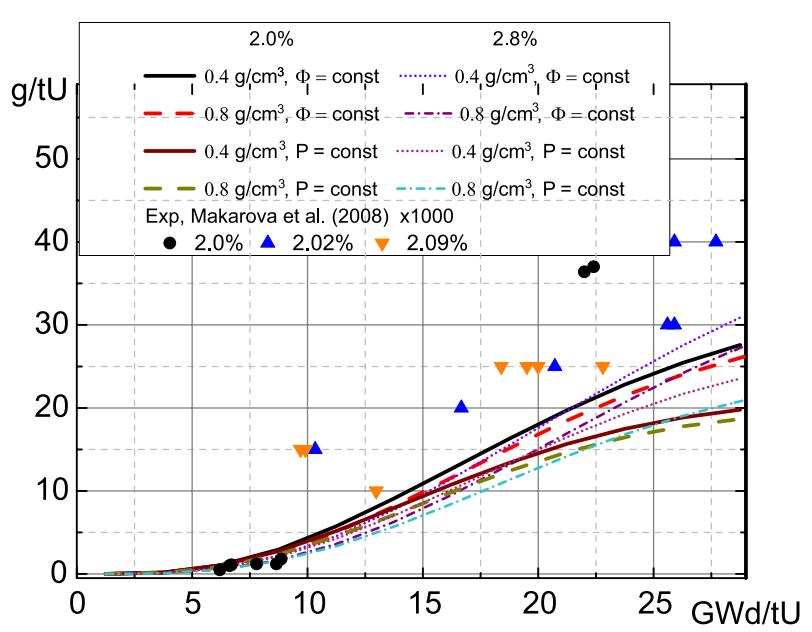

Fig. 10. ${ }^{241} \mathrm{Am}$ concentrations for different enrichment RBMK-1500 fuel calculated using generated neutron cross-section libraries in constant and constant power cases and experimental points from [6]. 
that the concentrations given in [6] are 1000 times lower, the experimental values in Fig. 10 are updated accordingly. In this case the results show a better agreement, especially at low burn-up.

The ${ }^{243} \mathrm{Am}$ (Fig. 11 ) concentration shows a good agreement with the experimental values with the difference up to $23 \%$, while ${ }^{237} \mathrm{~Np}$ (Fig. 12) has a difference of $22-29 \%$ for the $2 \%$ initial enrichment fuel. The experimental concentration values [6] of ${ }^{237} \mathrm{~Np}$ for the 2.02 and $2.09 \%$ initial enrichment fuel follow the trend of parent nuclide ${ }^{236} \mathrm{U}$.

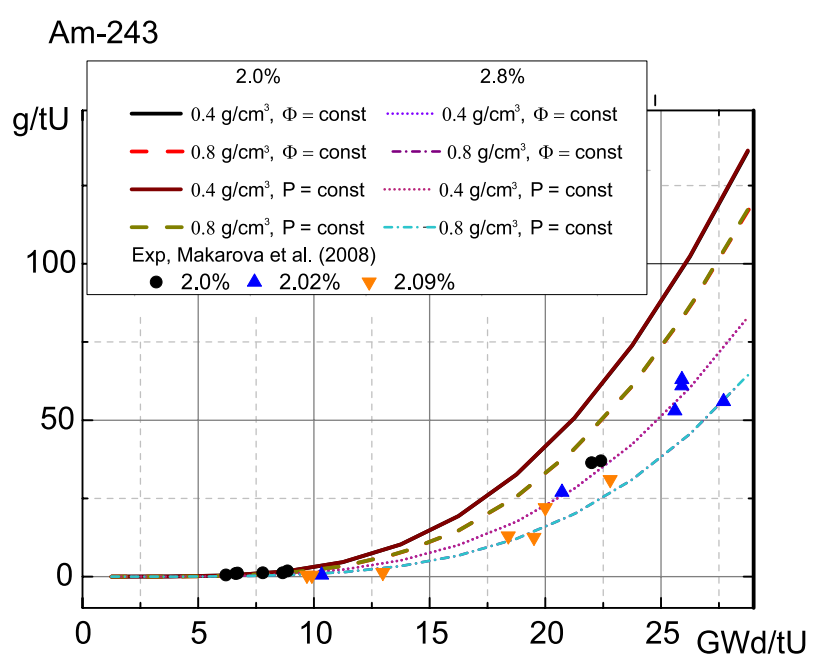

Fig. 11. ${ }^{243} \mathrm{Am}$ concentrations for different enrichment RBMK-1500 fuel calculated using generated neutron cross-section libraries in constant flux and constant power cases and experimental points from [6].

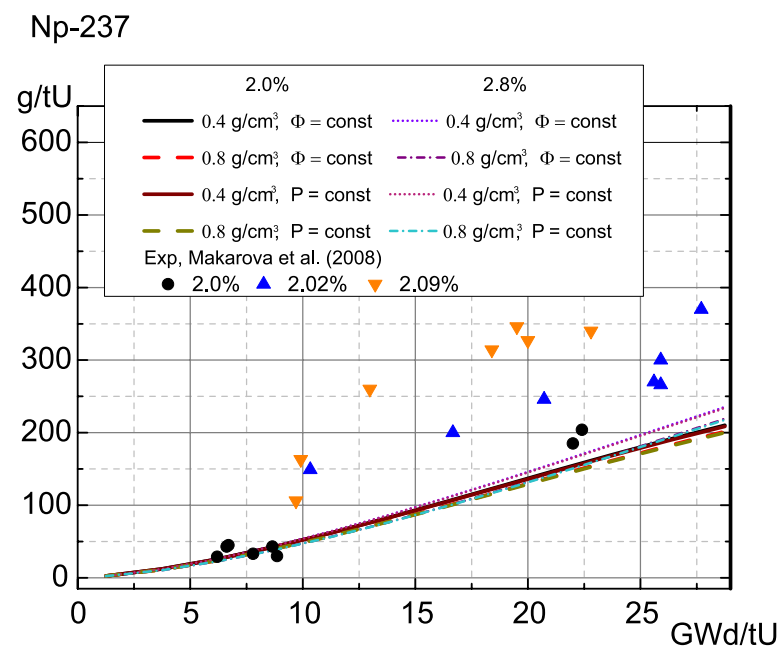

Fig. $12 .{ }^{237} \mathrm{~Np}$ concentrations for different enrichment RBMK-1500 fuel calculated using generated neutron cross-section libraries in constant flux and constant power cases and experimental points from [6].

\subsection{Curium}

The comparison of ${ }^{242} \mathrm{Cm}$ and ${ }^{244} \mathrm{Cm}$ TRITON modelling results [4] and experimental values [6] (see Figs. 13 and 14) shows a good agreement with the ORIGEN-ARP predictions of this study, except for ${ }^{244} \mathrm{Cm}$ in the case of high enrichment where differences reach up to $40 \%$.

\section{$\mathrm{Cm}-242$}

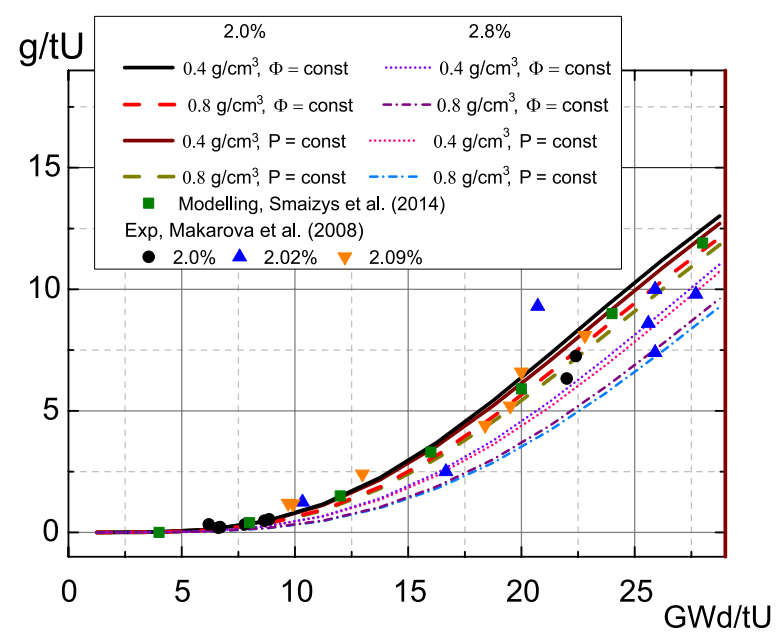

Fig. $13 .{ }^{242} \mathrm{Cm}$ concentrations for different enrichment RBMK-1500 fuel calculated using generated neutron cross-section libraries in constant flux and constant power cases and experimental points from [6] as well as point depletion modelling results from [4].

\section{$\mathrm{Cm}-244$}

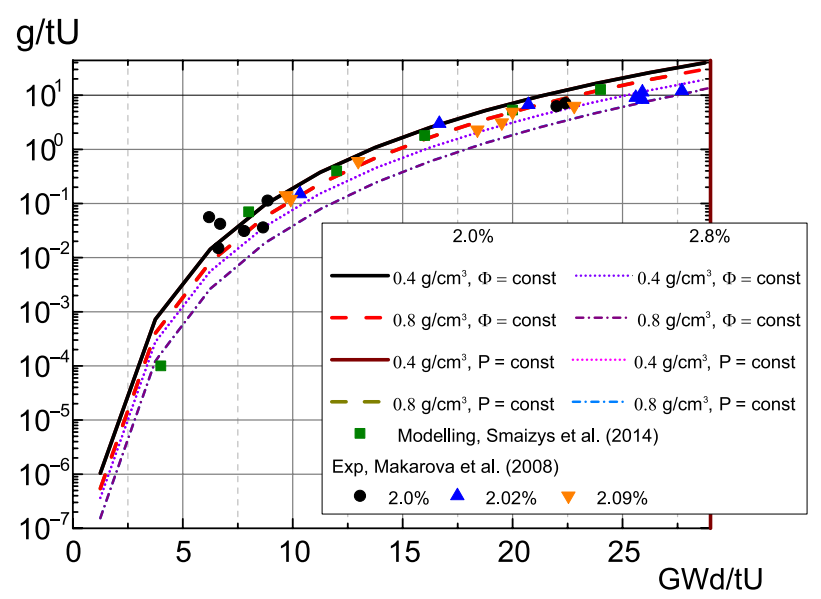

Fig. $14 .{ }^{244} \mathrm{Cm}$ concentrations for different enrichment RBMK-1500 fuel calculated using generated neutron cross-section libraries in constant flux and constant power cases and experimental points from [6] as well as point depletion modelling results from [4]. 


\subsection{Fission products}

Comparison with available experimental data given in [10] regarding fission products was also performed. Only the data of ${ }^{142} \mathrm{Nd},{ }^{143} \mathrm{Nd},{ }^{144} \mathrm{Nd},{ }^{145} \mathrm{Nd}$, ${ }^{146} \mathrm{Nd},{ }^{148} \mathrm{Nd}{ }^{150} \mathrm{Nd}$ and ${ }^{137} \mathrm{Cs}$ concentration measurements are available. A good agreement was observed between the modelling and experimental results of available fission product measurements, except for ${ }^{142} \mathrm{Nd}$ and ${ }^{144} \mathrm{Nd}$ (Figs. 16 and 18), where differences between the calculated and experimental values reach $50 \%$ for ${ }^{142} \mathrm{Nd}$.

\section{Cs-137}

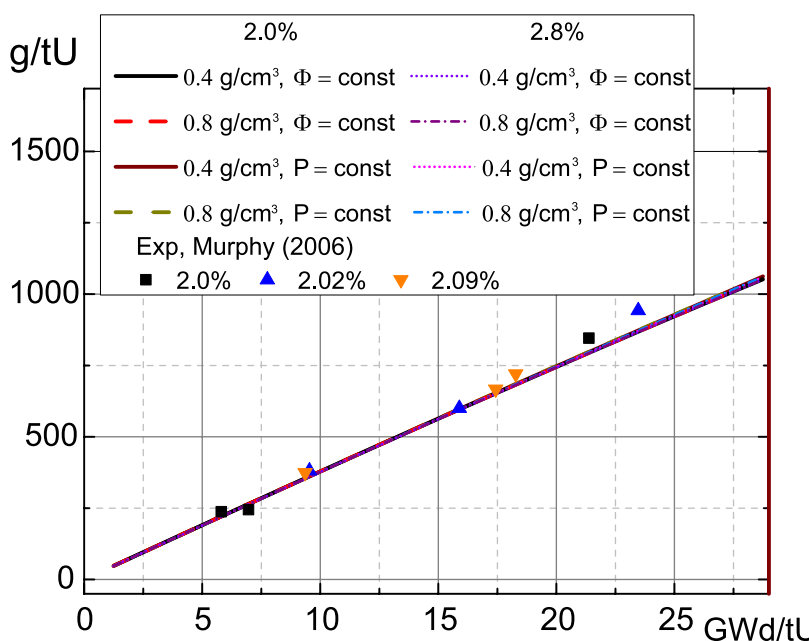

Fig. $15 .{ }^{137} \mathrm{Cs}$ concentrations for different enrichment RBMK-1500 fuel calculated using generated neutron cross-section libraries in constant flux and constant power cases and experimental points from [10].

$\mathrm{Nd}-142$

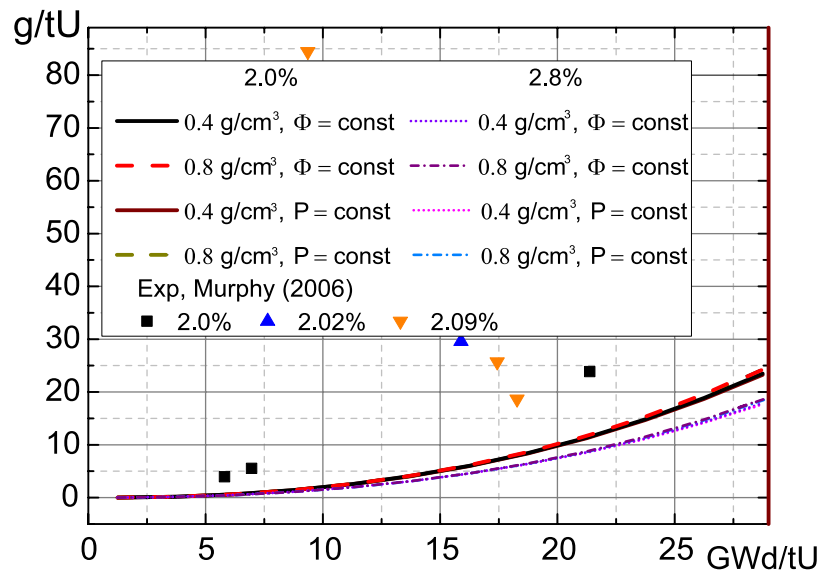

Fig. 16. ${ }^{142} \mathrm{Nd}$ concentrations for different enrichment RBMK-1500 fuel calculated using generated neutron cross-section libraries in constant flux and constant power cases and experimental points from [10].
Nd-143

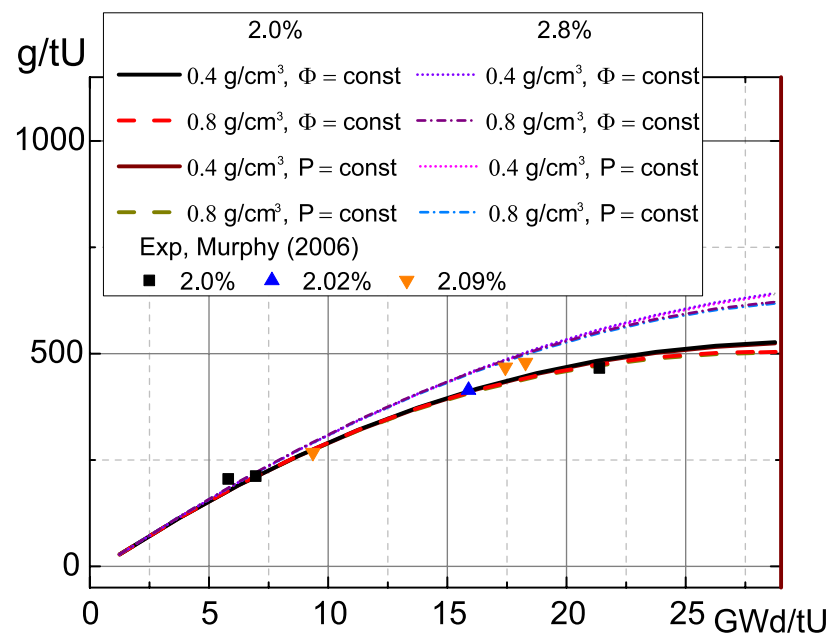

Fig. 17. ${ }^{143} \mathrm{Nd}$ concentrations for different enrichment RBMK-1500 fuel calculated using generated neutron cross-section libraries in constant flux and constant power cases and experimental points from [10].

\section{$\mathrm{Nd}-144$}

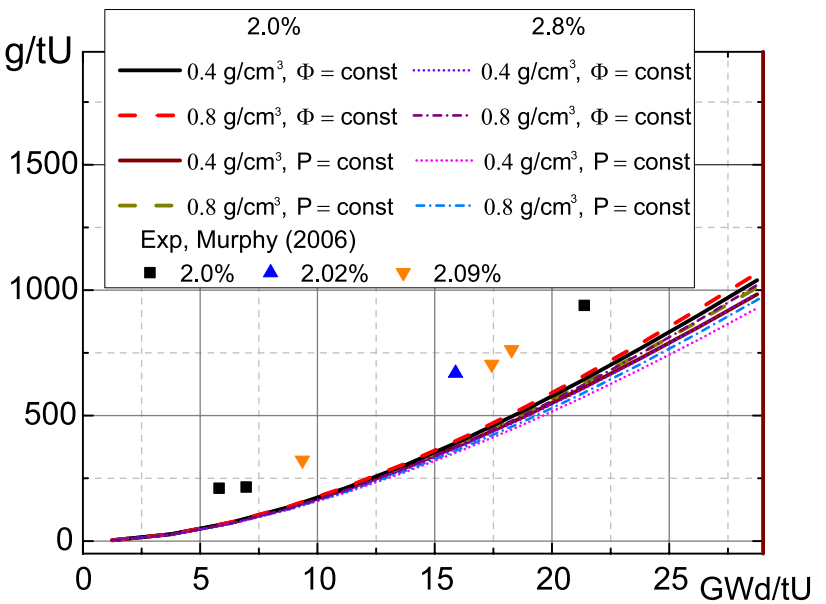

Fig. 18. ${ }^{144} \mathrm{Nd}$ concentrations for different enrichment RBMK-1500 fuel calculated using generated neutron cross-section libraries in constant flux and constant power cases and experimental points from [10].

\subsection{The role of enrichment and burnable absorber in the fuel}

The enrichment and burnable absorber plays an important role in the SNF composition. At the highest burn-up $(29 \mathrm{GWd} / \mathrm{tU})$ isotopic composition differences between the 2 and $2.8 \%$ enrichment fuel for the analysed actinides reach $60 \%$ for ${ }^{244} \mathrm{Cm}, 52 \%$ for ${ }^{243} \mathrm{Am}, 40 \%$ for ${ }^{241} \mathrm{Am}, 36 \%$ for ${ }^{242} \mathrm{Pu}, 32 \%$ for ${ }^{234} \mathrm{U}, 28 \%$ for ${ }^{238} \mathrm{Pu}, 27 \%$ for ${ }^{242} \mathrm{Cm}, 23 \%$ for ${ }^{236} \mathrm{U}, 15 \%$ for ${ }^{237} \mathrm{~Np}$, $14.5 \%$ for ${ }^{240} \mathrm{Pu}, 11.3 \%$ for ${ }^{241} \mathrm{Pu}$, and $11 \%$ for ${ }^{239} \mathrm{Pu}$. 


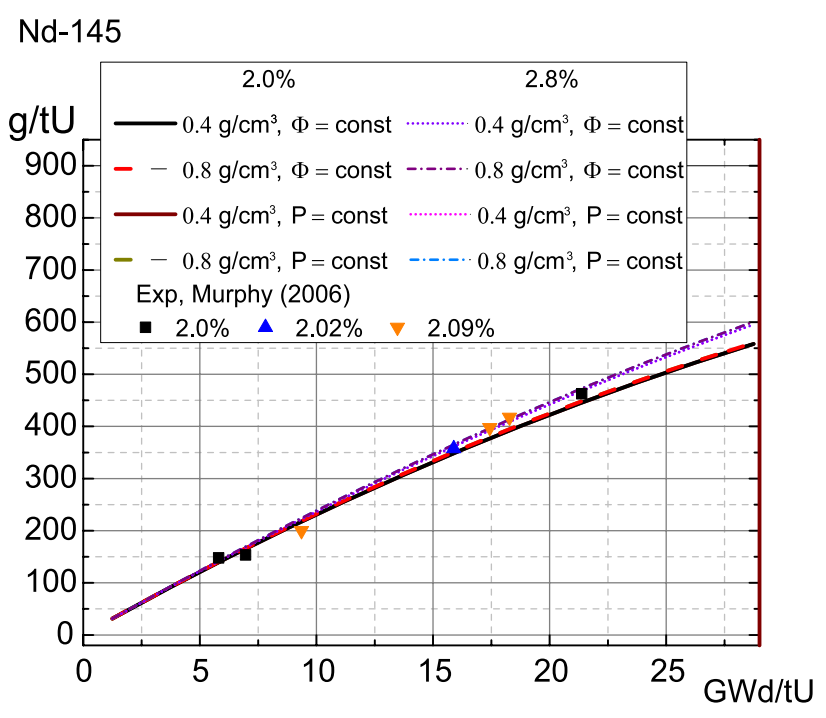

Fig. 19. ${ }^{145} \mathrm{Nd}$ concentrations for different enrichment RBMK-1500 fuel calculated using generated neutron cross-section libraries in constant flux and constant power cases and experimental points from [10].

$\mathrm{Nd}-146$

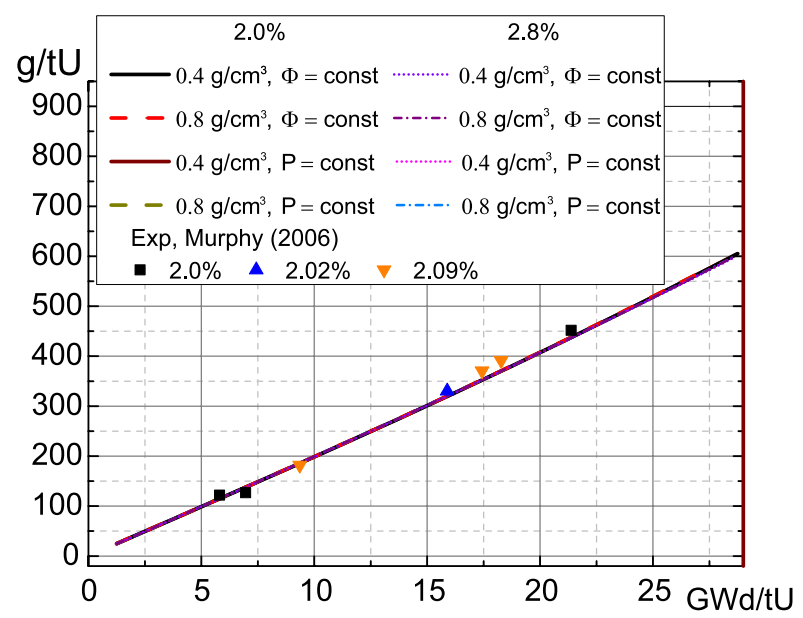

Fig. 20. ${ }^{146} \mathrm{Nd}$ concentrations for different enrichment RBMK-1500 fuel calculated using generated neutron cross-section libraries in constant flux and constant power cases and experimental points from [10].

According to [4] the initial enrichment of RBMK1000 fuel has no significant effect on the results of nuclide concentrations. The results obtained in this study show a different trend, especially for ${ }^{234} \mathrm{U},{ }^{236} \mathrm{U}$, ${ }^{237} \mathrm{~Np}$ and ${ }^{238} \mathrm{Pu}$. Fuel analyzed in [4] was of $1.8-2.2 \%$ enrichment without an erbium burnable absorber. Therefore, the conclusions regarding fuel enrichment in this study should be made not disconnecting different enrichment and the presence of a burnable absorber in the fuel.

Higher concentrations of ${ }^{243} \mathrm{Am},{ }^{241} \mathrm{Am}$ (at low burn-up only), ${ }^{242} \mathrm{Cm},{ }^{244} \mathrm{Cm},{ }^{238} \mathrm{Pu},{ }^{240} \mathrm{Pu}$ and ${ }^{242} \mathrm{Pu}$ are

\section{$\mathrm{Nd}-148$}

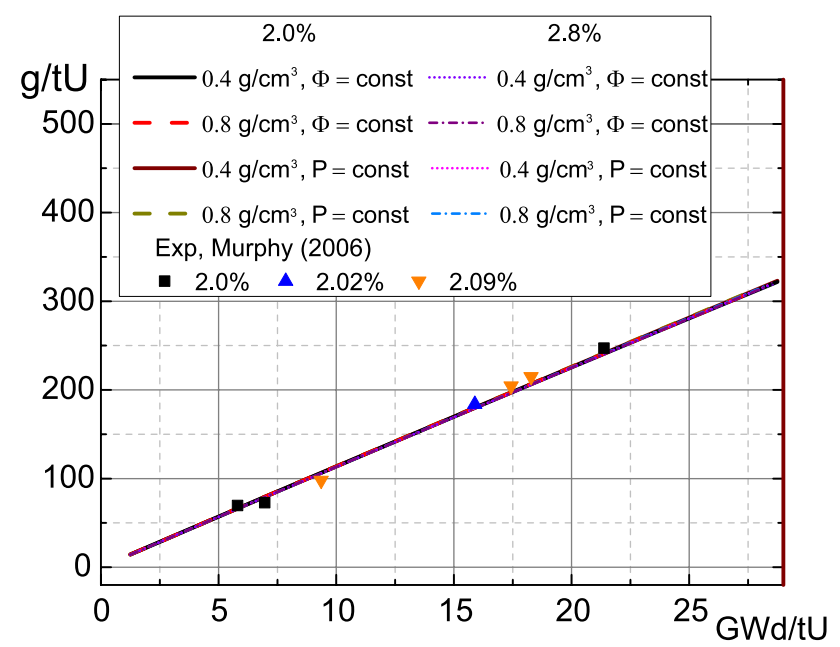

Fig. 21. ${ }^{148} \mathrm{Nd}$ concentrations for different enrichment RBMK-1500 fuel calculated using generated neutron cross-section libraries in constant flux and constant power cases and experimental points from [10].

\section{$\mathrm{Nd}-150$}

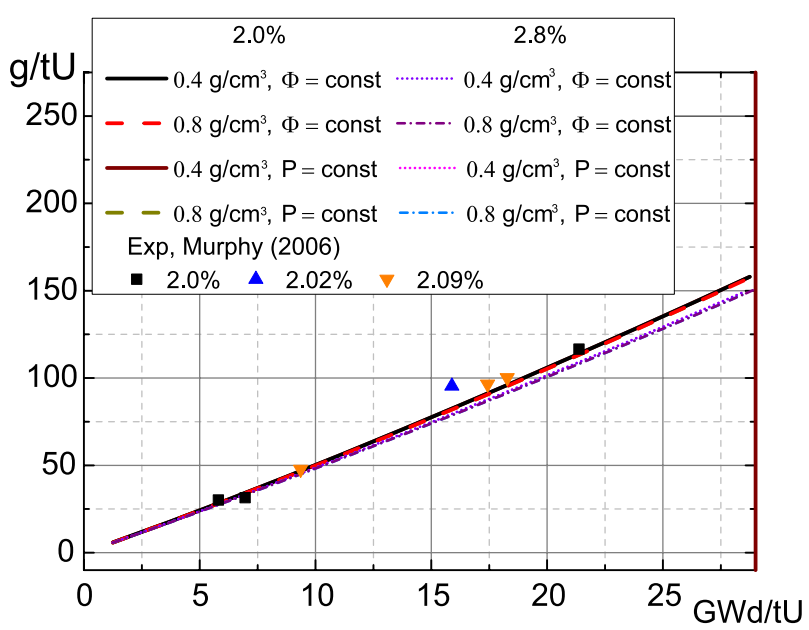

Fig. 22. ${ }^{150} \mathrm{Nd}$ concentrations for different enrichment RBMK-1500 fuel calculated using generated neutron cross-section libraries in constant flux and constant power cases and experimental points from [10].

calculated in the lower enrichment fuel of the same burn-up. Other nuclides show a higher concentration in the fuel of higher enrichment.

Regarding the $\mathrm{Nd}$ and $\mathrm{Cs}$ isotopes, a trend of a very low dependence on the fuel enrichment and the presence of a burnable absorber is noticed, but ${ }^{142} \mathrm{Nd}$ and ${ }^{143} \mathrm{Nd}$ show a different behaviour.

\subsection{Change of the SNF composition during irradiation}

${ }^{238} \mathrm{Pu},{ }^{239} \mathrm{Pu},{ }^{240} \mathrm{Pu},{ }^{241} \mathrm{Pu},{ }^{242} \mathrm{Pu},{ }^{237} \mathrm{~Np},{ }^{241} \mathrm{Am},{ }^{243} \mathrm{Am}$, ${ }^{242} \mathrm{Cm}$ and ${ }^{244} \mathrm{Cm}$ nuclides in this study emerge as acti- 
vation nuclides as the initial fuel composition without them is assumed. The concentrations of these nuclides increase with increasing burn-up, build-up rates of up to $29 \mathrm{GWd} / \mathrm{tU}$ of these nuclides exceed the burn-out and decay rate. The only exception is ${ }^{239} \mathrm{Pu}$, the concentration of which at around $23 \mathrm{GWd} / \mathrm{tU}$ reaches the maximum value and starts to decrease.

The initial concentrations of ${ }^{234} \mathrm{U}$ and ${ }^{235} \mathrm{U}$ decrease, while the concentration of ${ }^{236} \mathrm{U}$ increases with increasing burn-up. The decrease of ${ }^{234} \mathrm{U}$ is linear with increasing burn-up, while the build-up of ${ }^{236} \mathrm{U}$ and the burn-out of ${ }^{235} \mathrm{U}$ are slightly decreasing with higher burn-up.

\subsection{Constant power vs constant flux}

There are no significant differences between the constant flux and the constant power cases. The only nuclides, the concentrations of which are affected by a different modelling approach, are ${ }^{241} \mathrm{Am}$ and ${ }^{238} \mathrm{Pu}$. Difference for the ${ }^{241} \mathrm{Am}$ isotope is obtained due to its sensitivity to the neutron energy spectrum and the operational power (slightly variable in the constant flux case). It is assumed that the difference for ${ }^{238} \mathrm{Pu}$ is caused by the alpha decay of ${ }^{242} \mathrm{Cm}$ to ${ }^{238} \mathrm{Pu}$, as in the constant flux case the fuel is approximately 200 days longer in the reactor in comparison with the constant power case at the burn-up $29 \mathrm{GWd} / \mathrm{tU}$.

\subsection{Role of water density}

The role of coolant (water) density during fuel irradiation plays a crucial role in the precise evaluation of nuclide concentrations. The coolant density and the axial power profile have the largest influence on the considered physical reactor core parameters and fuel assembly conditions, therefore they should be modelled as close to real conditions as possible [3]. Nuclide concentration differences are mainly determined by differences in the neutron spectrum caused by different water density and fuel composition (Fig. 23).

Studies were also performed regarding differences of the nuclide formation in the inner and outer fuel rings of the same fuel channel, and conclusions were drawn that the reason for the differences was the neutron flux variations and the heterogeneous neutron absorption, because the harder neutron spectrum is in the inner fuel rods ring of the assembly and more neutrons are absorbed in the lower part of the assembly due to the higher density of water (less neutrons are available for fission reaction) [2].

According to $[3],{ }^{238} \mathrm{Pu},{ }^{241} \mathrm{Pu}$ and ${ }^{243} \mathrm{Am}$ are the actinides most sensitive to coolant density variation. The production of ${ }^{241} \mathrm{Pu}$ in the SNF can vary up to

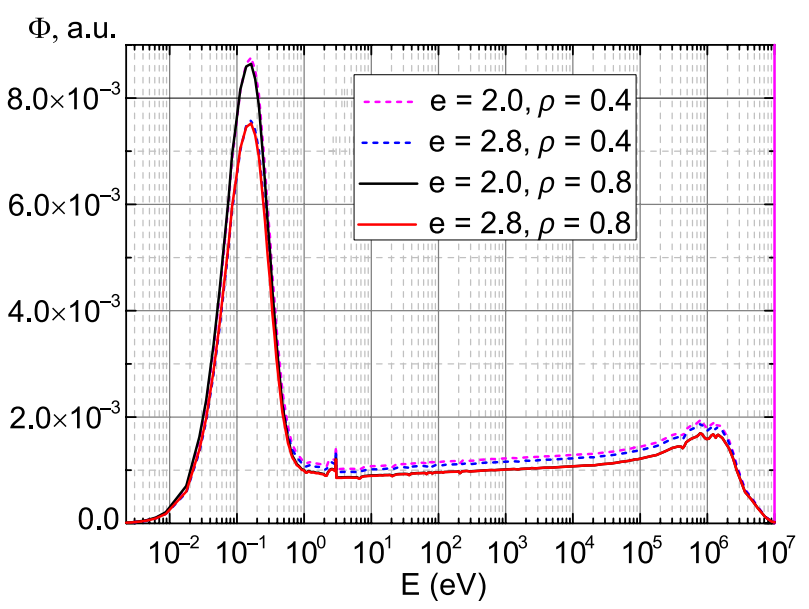

Fig. 23. Neutron flux per unit lethargy spectra for 2.0 and $2.8 \%$ enrichment fuel in the case of 0.4 and $0.8 \mathrm{~g} / \mathrm{cm}^{3}$ water density inside the RBMK-1500 reactor fuel channel.

$5 \%$ for different fuel assembly positions at a different fuel burn-up. Variations in the thermal neutron spectrum affect the production of ${ }^{240} \mathrm{Pu}$ and subsequently the production of ${ }^{241} \mathrm{Pu}$ by the neutron capture reaction [2]. The results of this study show that ${ }^{242} \mathrm{Cm}$ and ${ }^{244} \mathrm{Cm}$ are also quite sensitive to the coolant density (difference of $25 \%$ at higher burn-up), while the evaluation of ${ }^{241} \mathrm{Pu}$ shows the same sensitivity.

The calculation of fuel depletion in RBMK-1500 shows that the concentration curves corresponding to different enrichment and water density values, which vary from 0.4 to $0.8 \mathrm{~g} / \mathrm{cm}^{3}$, form four sets for every enrichment value $(2.0,2.4,2.6,2.8 \%)$, while the limiting cases, which bound possible nuclide concentrations, are $2.0 \%$ enrichment fuel (without erbium), $0.4 \mathrm{~g} / \mathrm{cm}^{3}$ water density and $2.8 \%$ enrichment, $0.8 \mathrm{~g} / \mathrm{cm}^{3}$ water density. At the highest burnup $(29 \mathrm{GWd} / \mathrm{tU})$ the isotopic composition differences between 0.4 and $0.8 \mathrm{~g} / \mathrm{cm}^{3}$ for actinides important to BUC applications reach 14 for the $2 \%$ enrichment fuel and 22 for the $2.8 \%$ enrichment fuel.

\section{Conclusions}

Calculations of fuel depletion in the RBMK-1500 type reactor using the infinite reactor macro lattice $(4 \times 4)$ were performed, and one-group cross-section libraries were created for SNF composition calculations for $2.0-2.8 \%$ enrichment fuel without and with an erbium burnable absorber. Concentrations of actinides important to the burn-up credit evaluation and $\mathrm{Cm}$ isotopes were obtained using the generated one-group cross-section libraries and were compared to available experimental data and the newest 
modelling results. The comparison shows an acceptable agreement between the values obtained using created one-group cross-section libraries and experimental data as well as point depletion calculations. The exception was observed only for ${ }^{238} \mathrm{Pu}$, which was caused by the initial composition of nuclear fuel, and ${ }^{241} \mathrm{Am}$, most probably due to incorrect experimental values given, as other studies show results similar to the calculation results of this study. The comparison with available experimental data regarding the fission products ${ }^{142} \mathrm{Nd},{ }^{143} \mathrm{Nd}$, ${ }^{144} \mathrm{Nd},{ }^{145} \mathrm{Nd},{ }^{146} \mathrm{Nd},{ }^{148} \mathrm{Nd},{ }^{150} \mathrm{Nd}$ and ${ }^{137} \mathrm{Cs}$ was also performed. The fission product evaluation shows a good agreement with the experimental data except for ${ }^{142} \mathrm{Nd}$ and ${ }^{144} \mathrm{Nd}$ isotopes.

The enrichment and presence of the burnable absorber play an important role in the SNF composition. At the highest modelled burn-up $(29 \mathrm{GWd} / \mathrm{tU})$ the isotopic composition differences between 2 and $2.8 \%$ enrichment fuel burn-up for actinides important to BUC applications vary from 11 to $52 \%$.

The coolant (water) density in the water channel during burn-up plays the crucial role in the precise evaluation of nuclide concentrations. These differences are mainly determined by differences in the neutron spectrum caused by the water density and the fuel composition. At the highest burn-up ( $29 \mathrm{GWd} / \mathrm{tU})$ isotopic composition differences between 0.4 and $0.8 \mathrm{~g} / \mathrm{cm}^{3}$ for actinides important to BUC applications reach $14 \%$ for $2 \%$ enrichment fuel and $22 \%$ for $2.8 \%$ enrichment fuel. The obtained libraries could be applied to the evaluation of the RBMK-1500 spent nuclear fuel using the actinide-only approach in burnup credit calculations, as well as for other purposes, e. g. for the activity or toxicity evaluation of spent nuclear fuel.

\section{References}

[1] A.M. Bolind, The use of the BIC set in the characterization of used nuclear fuel assemblies by nondestructive assay, Annal. Nucl. Energy 66, 31-50 (2014).

[2] R. Plukienè, A. Plukis, V. Remeikis, and D. Ridikas, MCNP and ORIGEN codes validation by calculating RBMK spent nuclear fuel isotopic composition, Lith. J. Phys. 45(4), 281-287 (2005).

[3] R. Plukienè, A. Plukis, D. Germanas, and V. Remeikis, Numerical sensitivity study of irradiated nuclear fuel evolution in the RBMK reactor, Lith. J. Phys. 49(4), 461-469 (2009).

[4] A. Šmaižys, P. Poškas, E. Narkūnas, and G. Bartkus, Numerical modelling of radionuclide inventory for RBMK irradiated nuclear fuel, Nucl. Eng. Des. 277, 28-35 (2014).
[5] A.G. Korenkov, T.P. Makarova, A.V. Stepanov, E.V. Pevtsova, B.N. Belyaev, and A.A. Voronkov, Destructive analysis determination of neutron emission from spent RBMK fuel, Atom. Energy 93(4), 815-822 (2002).

[6] T.P. Makarova, B.A. Bibichev, and V.D. Domkin, Destructive analysis of the nuclide composition of spent fuel of WWER-440, WWER-1000, and RBMK-1000 reactors, Radiochemistry 50(4), 414426 (2008).

[7] M.W. Francis, Reactor Fuel Isotopics and Code Validation for Nuclear Applications (Oak Ridge National Laboratory, 2014).

[8] B.D. Murphy, ORIGEN-ARP Cross-Section Libraries for Magnox, Advanced Gas-Cooled, and VVER Reactor Designs (Oak Ridge National Laboratory, 2004).

[9] G. Ilas, I.C. Gauld, and V. Jodoin, LWR cross section libraries for ORIGEN-ARP in SCALE 5.1, Trans. Am. Nucl. Soc. 95, 706-708 (2006).

[10]B.D. Murphy, ORIGEN-ARP Cross-Section Libraries for the RBMK-1000 System (Oak Ridge National Laboratory, 2006).

[11] Nuclear Energy Agency, Spent Nuclear Fuel Assay Data for Isotopic Validation, State-of-the-art Report (OECD, 2011).

[12] J.S. Kim, Y.S. Jeon, S.D. Park, Y.K. Ha, and K. Song, Burnup determination of high burnup and dry processed fuels based on isotope dilution mass spectrometric measurements, J. Nucl. Sci. Technol. 44(7), 1015-1023 (2007).

[13]A. Šmaižys, Analysis of Nuclear and Radiation Characteristics of RBMK-1500 Spent Nuclear Fuel Casks and Storage Facilities, $\mathrm{PhD}$ Thesis (Kaunas, 2004).

[14] Y.P. Kovbasenko and M.L. Yeremenko, Opredeleniye izotopnovo sostava otpabotavshevo topliva reaktorov RBMK dlya posleduyushchevo analiza yadernoy bezopasnosti s uchëtom vygoraniya topliva,Yaderna ta Radiatsiyna Bezpeka [Nuclear and Radiation Safety] 2(50), 35-42 (2011) [in Russian].

[15] A. Šmaižys and P. Poškas, in: Practices and Developments in Spent Fuel Burnup Credit Applications, Proceedings of a Technical Committee Meeting (International Atomic Energy Agency, Vienna, Austria, 2003).

[16] Lithuanian Energy Institute, GNS-NUKEM Consortium, Interim Storage of RBMK Spent Nuclear Fuel from Ignalina NPP Units 1 and 2, Environmental Impact Assessment Report (2007).

[17] S.M. Bowman, SCALE 6: Comprehensive Nuclear Safety Analysis Code System, Nucl. Technol. 174(2), 126-148 (2011).

[18] I.C. Gauld, P. Chare, and R.C. Clarke, Development of ORIGEN-ARP Methods and Data for LEU and MOX Safeguards Applications, Submitted to 44th Annual Institute of Nuclear Materials Management (INMM) Annual Meeting (Phoenix, Arizona, USA, 2003). 
[19] K. Almenas, A. Kaliatka, and E. Uspuras, Ignalina RBMK-1500. A Source Book (Lithuanian Energy Institute, 1998).

[20] V. Remeikis and A. Jurkevicius, Evolution of the neutron sensor characteristics in the RBMK1500 reactor neutron flux, Nucl. Eng. Des. 231(3), 271-282 (2004).
[21]A.S. Chambers, A Comparison of Nuclide Production and Depletion using MCNPX and ORIGENARP Reactor Models and a Sensitivity Study of Reactor Design Parameters Using MCNPX for Nuclear Forensics Purposes, PhD Thesis (The University of Texas at Austin, 2010).

\title{
RBMK-1500 PANAUDOTO BRANDUOLINIO KURO SKERSPJŪVIŲ BIBLIOTEKŲ SUDARYMAS IR JŲ İVERTINIMAS ATSIŽVELGIANT İ EKSPERIMENTINIUS DUOMENIS
}

\author{
V. Barkauskas, R. Plukienė, A. Plukis, V. Remeikis \\ Fiziniu ir technologijos mokslų centro Fizikos institutas, Vilnius, Lietuva
}

\begin{abstract}
Santrauka
Skaitmeniškai modeliuotas RBMK-1500 reaktoriaus skirtingai įsodrinto kuro nuklidinès sudèties kitimas reaktoriuje. Modeliuojant sudarytos vienos energijos grupès skerspjūvių bibliotekos, skirtos Origen-ARP programai. Nuklidinès sudèties kitimo skaičiavimai atlikti naudojantis SCALE 6.1 programų paketo TRITON moduliu, kuriame neutronų pernašos lygtis sprendžiama su NEWT deterministinio skaičiavimo programa. Skaičiavimams naudota 238 energijos grupių nuklidų skerspjūvių biblioteka ENDF-B VII. Apšvitinto branduolinio kuro nuklidine sudètis ịvertinta su ORIGEN-S programa. Naudojantis sudarytomis vienos grupès bibliotekomis buvo ịvertintos kritiškumo saugai svarbiausių aktinoidų koncentracijos ir jos palygintos su prieinamais
\end{abstract}

eksperimentiniais duomenimis bei kitų mokslininkų skaičiavimų rezultatais. Su eksperimentiniais duomenimis taip pat palygintos ir dalijimosi produktų (Cs ir Nd izotopų) koncentracijos. Nustatyti sudèties skirtumai esant skirtingam branduolinio kuro įsodrinimui ir šilumnešio (vandens) tankiui eksploatavimo metu. Palyginimas rodo patenkinamą nuklidų koncentracijų skaitinio modeliavimo ir eksperimentinių verčių atitikimą, išskyrus ${ }^{238} \mathrm{Pu}$ ir ${ }^{241} \mathrm{Am}$ nuklidų koncentracijas. Darbe aptartos šių neatitikimų priežastys. Nustatyta, kad įsodrinimas ir išdegantis sugèriklis turi didelę ịtaką panaudoto branduolinio kuro sudečiai. Esant didžiausiai analizuotai išdegimo vertei $(29 \mathrm{GWd} / \mathrm{tU})$ kritiškumo saugai svarbių aktinoidų koncentracijų skirtumai nuo 2 iki 2,8 \% ísodrinimo kuro sudarè 11-52\%. 